\title{
Evaluation of the Potential of Sewage Sludge for Manufacturing Substrate for Passion Fruit Seedlings
}

\author{
Israel Martins Pereira ${ }^{1}$, Alex Justino Zacarias ${ }^{2}$, Rebyson Bissaco Guidinelle ${ }^{2}$, Julio Cesar Gradice Saluci ${ }^{1}$, \\ Mário E. P. da Costa Jaeggi ${ }^{1}$, André Oliveira Souza ${ }^{2}$, Derivaldo Pureza da Cruz ${ }^{1}$, \\ Camila Q. da S. Sanfim de Sant'Anna ${ }^{1}$, Tâmara R. Albuquerque de Oliveira ${ }^{1}$, Richardson Sales Rocha ${ }^{1}$, \\ Geraldo de Amaral Gravina ${ }^{1} \&$ Wallace Luís de Lima ${ }^{2}$ \\ ${ }^{1}$ Postgraduate Program in Plant Production, State University of North Fluminense, Campos dos Goytacazes, RJ, \\ Brazil \\ ${ }^{2}$ Postgraduate Program in Agroecology, Federal Institute of Espírito Santo, Alegre, ES, Brazil \\ Correspondence: Richardson Sales Rocha, Postgraduate Program in Plant Production, State University of North \\ Fluminense, Av. Alberto Lamego, 2000. Parque California, 28035-200, Campos dos Goytacazes, RJ, Brazil. \\ E-mail: richardson_sales@hotmail.com
}

Received: November 10, 2019

doi:10.5539/jas.v12n4p262
Accepted: December 24, 2019 Online Published: March 15, 2020

URL: https://doi.org/10.5539/jas.v12n4p262

\begin{abstract}
Brazil is the world's largest producer and largest consumer of passion fruit, producing approximately 0.1 million tons. However, crop management techniques are deficient in the use of alternative sources of fertilizer, an extremely relevant aspect in reducing production costs, as some nutrients are imported at high costs. Thus, this study was intended to calculate the percentage of an optimal dose of sewage sludge according to the regression model for each morpho-agronomic trait of yellow passion fruit. A completely randomized design (CRD) was adopted, consisting of four treatments, $0 ; 25 ; 50$; and 75\%, with 20 replicates considering one plant per replicate. Treatments were T1 ( 0 without sewage sludge addition), T2 (75\% soil $+25 \%$ sewage sludge); T3 (50\% soil + $50 \%$ sewage sludge); and T4 (25\% soil $+75 \%$ sewage sludge). Regression coefficients were above $80 \%$. Morpho-agronomic traits obtained optimal doses at a concentration of $50 \%$ of sewage sludge for the manufacture of the substrate. The conclusion reached was the substrate based on sewage sludge in the proportion of $50 \%$ combined with $50 \%$ of soil was superior to the other ones for seedling production.
\end{abstract}

Keywords: morphological, passion fruit, production

\section{Introduction}

Passiflora edulis S., or passion fruit, is a tropical species with a high content of vitamin C, B1 and B2, pro-vitamin A, $\beta$-carotene, besides minerals and fibers (Freitas et al., 2011). Brazil offers more than 150 varieties of passion fruit, although the yellow or bitter one represents more than $95 \%$ of Brazilian yield (Sabião et al., 2011). The country is the third largest producer globally, with 43 million tons of passion fruit (Pacheco et al., 2016).

Despite high production, Brazilian orchards have low yields, due to the lack of technologies that enable producers to solve problems related to plant health and management, and the lack of improved genotypes (Faleiro et al., 2008; Aguiar et al., 2015; Cezar et al., 2015; Pacheco et al., 2016).

For Souza et al. (2015), a broad scientific field is still to be explored for such a crop, making it possible to develop technological packages to enhance techniques for growing passion fruit. Seedling stage is one of the most significant periods for the proper development of commercially-grown species. Substrate is one of the criteria that must be observed, which should consist of materials that present good physical and chemical characteristics required for plant growth (Cavalcante, Cavalcante, dos Santos, Beckmann Cavalcante, \& Silva, 2012; Maggio, De Pascale, Paradiso, \& Barbieri, 2013).

In this regard, sewage sludge, a by-product of wastewater treatment from treatment plants with biological, physical and chemical characteristics desirable for its use in agricultural areas (Moraes Neto et al., 2007), appears as a viable alternative of use to the initial seedling growth, because it is an excellent supplier of organic 
matter and, therefore, capable of improving the physical properties of soils (Jorge et al., 1991; McBride, 2003; McLaren et al., 2004; de las Heras et al., 2005).

The enrichment of substrates by sewage sludge, rich in phosphorus, nitrogen, and other nutrients, with lower concentrations, is a viable alternative for their final destination, resulting in savings in fertilizers and environmental benefits (Trigueiro \& Guerrini, 2003). The adoption of sewage sludge as a substrate to produce seedlings may contribute to minimizing environmental contamination by potentially toxic elements (Rocha et al., 2013).

Thus, for this work, we aimed at evaluating the effect of different concentrations of sewage sludge added to the conventional substrate on the development and quality of yellow passion fruit seedlings.

\section{Material and Methods}

\subsection{Study Sites}

The experiment was conducted at the Instituto Federal do Espírito Santo (IFES)-campus Alegre, located in the Municipality of Alegre, Espírito Santo State, Brazil, latitude of $20^{\circ} 45^{\prime} 44^{\prime \prime}$ south, longitude of $41^{\circ} 27^{\prime} 43^{\prime \prime}$ west, and altitude of 134 meters. Following Köppen classification, the climate in the region is Aw-type, dry winter, rainy summer, with a mean annual temperature of $23^{\circ} \mathrm{C}$ and an annual rainfall of around $1,200 \mathrm{~mm}$.

The design was completely randomized (CRD), consisting of four treatments, $0 ; 25 ; 50 ; 75 \%$, constituting 20 replicates. The experimental plot consisted of a $679 \mathrm{~cm}^{3}$ - plastic bag with a yellow passion fruit plant of the variety Passiflora edulis f. flavicarpa.

Treatments were T1: (without sewage sludge addition); T2: (75\% soil $+25 \%$ sewage sludge); $\mathrm{T} 3:(50 \%$ soil $+50 \%$ sewage sludge); and T4: ( $25 \%$ soil $+75 \%$ sewage sludge) .

For substrate composition, Red-Yellow Latosol taken from the Zootechnical Sector of IFES-campus Alegre was used. The soil was sieved on a 4-mm sieve. A chemical analysis of this material was performed at the laboratory of Bromatology in IFES-campus Alegre (Table 1).

Table 1. Chemical characterization of the soil used in passion fruit seedling production

\begin{tabular}{ll}
\hline Trait & Content \\
\hline $\mathrm{pH}\left(\mathrm{H}_{2} 0\right)$ & 5.29 \\
$\mathrm{P}$ & $8.03 \mathrm{Mg} / \mathrm{dm}^{3}$ \\
$\mathrm{~K}$ & $36 \mathrm{Mg} / \mathrm{dm}^{3}$ \\
$\mathrm{Na}$ & $0.0 \mathrm{Mg} / \mathrm{dm}^{3}$ \\
$\mathrm{Ca}$ & $0.87 \mathrm{Cmolc} / \mathrm{dm}^{3}$ \\
$\mathrm{Mg}$ & $1.17 \mathrm{Cmolc} / \mathrm{dm}^{3}$ \\
$\mathrm{Al}$ & $0.10 \mathrm{Cmolc} / \mathrm{dm}^{3}$ \\
$\mathrm{H}+\mathrm{Al}$ & $2.64 \mathrm{Cmolc} / \mathrm{dm}^{3}$ \\
$\mathrm{SB}$ & $2.13 \mathrm{Cmolc} / \mathrm{dm}^{3}$ \\
$\mathrm{~T}$ & $2.23 \mathrm{Cmolc} / \mathrm{dm}^{3}$ \\
$\mathrm{~T}$ & $4.77 \mathrm{Cmolc} / \mathrm{dm}^{3}$ \\
$\mathrm{~V}$ & $44.66 \%$ \\
$\mathrm{M}$ & $4.48 \%$ \\
\hline
\end{tabular}

This sewage sludge was collected at the sewage treatment plant, located in the Municipality of Cachoeiro de Itapemirim, Espírito Santo State, Brazil, and dehydrated at room temperature in a greenhouse. Dry material was crushed with manual tools and sieved in a 4-mm mesh. Its chemical analysis was performed in the Chemistry Laboratory of IFES-campus Alegre (Table 2). 
Table 2. Chemical characterization of sewage sludge used in the yield of passion fruit seedlings

\begin{tabular}{ll}
\hline Trait & Content $(\mathrm{g} / \mathrm{kg})$ \\
\hline Nitrogen & 40.60 \\
Phosphorus & 8.20 \\
Potassium & 16.30 \\
Calcium & 16.40 \\
Magnesium & 4.20 \\
Sulphur & 2.70 \\
Boron & 0.0542 \\
Zinc & 0.178 \\
Manganese & 0.49 \\
Iron & 0.50 \\
Copper & 0.0784 \\
\hline
\end{tabular}

Polyethylene bags with a volumetric capacity of $769 \mathrm{~cm}^{3}$ were used. The substrate was exposed to an incubation period of seven days, receiving only daily irrigation. Sowing was then carried out by placing three seeds per container at a 2-cm depth. At ten days after emergence (DAE), thinning was performed leaving only one plant per container. Throughout the experimental period, seedlings were irrigated according to crop recommendations (Sousa et al., 2005).

Evaluations were performed 70 days after sowing. The variables evaluated were the following ones:

- $\quad$ Plant height (PHEI) in centimeters: determined by a millimeter rule;

- $\quad$ Root length (RLEN) in centimeters: determined by a millimeter rule;

- Root collar diameter (RCD): obtained by means of a digital caliper measured from the root collar plant expressed in (mm);

- Number of leaves (NL): obtained by direct counting of leaves on each plant;

- Total fresh matter (TFM): obtained by a digital scale;

- Total dry matter (TDM): obtained by a digital scale after drying in a forced-air oven at $75{ }^{\circ} \mathrm{C}$ up to a constant weight;

- Dickson quality index: obtained by the equation DQI $=[$ Total dry matter/(Height/Diameter ratio + Aerial part/Root ratio)] (Dickson et al., 1960);

- Aerial part/root ratio: obtained by the equation DMAP/RDM;

- Ratio plant height and root collar diameter: obtained by the equation PHEI/RCD.

Data were submitted for analysis of variance (ANOVA) and, subsequently, to regression analysis with SISVAR software version 5.3 (Ferreira, 2011).

\section{Results and Discussion}

The morphological traits evaluated during the experiment showed different responses from each other. From the regression analysis, there was no significant effect on the lack of it of the regression model in all the evaluated traits; the coefficients of determination of the tested models were over $85 \%$, proving that the models were well adjusted, in other words, most of the variability existing in the response variable can be explained by the doses of compounds applied. This makes it possible to obtain, more accurately, estimates of optimal doses of a compound that should be recommended for passion fruit crops (Table 3). 
Table 3. Second-order linear regression analysis for the following traits: plant height (PHEI), root length (RLEN), root collar diameter (RCD), number of leaves (NL), total fresh matter (TFM), fresh matter of aerial part (FMAP), root fresh matter (RFM), total dry matter (TDM), dry matter of aerial part (DMAP), and root dry matter (RDM), with significant optimal doses $(\mathrm{p}<0.01)$ for all varieties under study

\begin{tabular}{|c|c|c|c|c|c|}
\hline Variables & Quadratic Model & Estimates & Lack of it (p valor) & $\mathrm{R}^{2}(\%)$ & Great dose (\%) \\
\hline \multirow{3}{*}{ PHEI } & $\beta_{0}$ & 197.4375 & \multirow{3}{*}{$0.1177^{\mathrm{ns}}$} & \multirow{3}{*}{88.32} & \multirow{3}{*}{25.44} \\
\hline & $\beta_{1}$ & 1.2975 & & & \\
\hline & $\beta_{2}$ & -0.0255 & & & \\
\hline \multirow{2}{*}{ RLEN } & $\beta_{0}$ & 106.6265 & \multirow{2}{*}{$0.1819^{\mathrm{ns}}$} & \multirow{2}{*}{88.30} & \multirow{2}{*}{42.00} \\
\hline & $\beta_{1}$ & -0.7020 & & & \\
\hline \multirow{3}{*}{$\mathrm{RCD}$} & $\beta_{0}$ & 1.1884 & \multirow{3}{*}{$0.1830^{\mathrm{ns}}$} & \multirow{3}{*}{96.58} & \multirow{3}{*}{46.87} \\
\hline & $\beta_{1}$ & 0.0375 & & & \\
\hline & $\beta_{2}$ & -0.0004 & & & \\
\hline \multirow{3}{*}{ NL } & $\beta_{0}$ & 4.9688 & \multirow{3}{*}{$0.5445^{\mathrm{ns}}$} & \multirow{3}{*}{99.56} & \multirow{3}{*}{42.21} \\
\hline & $\beta_{1}$ & 0.1238 & & & \\
\hline & $\beta_{2}$ & -0.0014 & & & \\
\hline \multirow{3}{*}{ TFM } & $\beta_{0}$ & 0.5211 & \multirow{3}{*}{$0.3511^{\mathrm{ns}}$} & \multirow{3}{*}{98.06} & \multirow{3}{*}{41.95} \\
\hline & $\beta_{1}$ & 0.0923 & & & \\
\hline & $\beta_{2}$ & -0.0011 & & & \\
\hline \multirow{3}{*}{ FMAP } & $\beta_{0}$ & 0.4298 & \multirow{3}{*}{$0.2736^{\mathrm{ns}}$} & \multirow{3}{*}{97.38} & \multirow{3}{*}{39.91} \\
\hline & $\beta_{1}$ & 0.0878 & & & \\
\hline & $\beta_{2}$ & -0.0011 & & & \\
\hline \multirow{3}{*}{ RFM } & $\beta_{0}$ & 0.0913 & \multirow{3}{*}{$0.1858^{\mathrm{ns}}$} & \multirow{3}{*}{93.22} & \multirow{3}{*}{22.50} \\
\hline & $\beta_{1}$ & 0.0045 & & & \\
\hline & $\beta_{2}$ & -0.0001 & & & \\
\hline \multirow{3}{*}{ TDM } & $\beta_{0}$ & 0.0808 & \multirow{3}{*}{$0.1755^{\mathrm{ns}}$} & \multirow{3}{*}{95.21} & \\
\hline & $\beta_{1}$ & 0.0115 & & & 57.60 \\
\hline & $\beta_{2}$ & -0.0001 & & & \\
\hline & $\beta_{0}$ & 0.0696 & & & \\
\hline DMAP & $\beta_{1}$ & 0.0107 & $0.1932^{\mathrm{ns}}$ & 94.68 & 53.50 \\
\hline & $\beta_{2}$ & -0.0001 & & & \\
\hline & $\beta_{0}$ & 0.0112 & & & \\
\hline RDM & $\beta_{1}$ & 0.0007 & $0.0580^{\mathrm{ns}}$ & 85.81 & 38.89 \\
\hline & $\beta_{2}$ & -0.000009 & & & \\
\hline
\end{tabular}

The proportion of 22.50 to $57.60 \%$ of sewage sludge, combined with $50 \%$ of subsoil T2 and T3, showed higher values for all traits evaluated in comparison to treatment T4. Maya (1999) found similar results by using subsoil, sewage sludge, and pine bark as substrate for Pinus taeda seedling production, in which he proved that the presence of subsoil in the substrate is unnecessary and that sludge, on the other hand, should not be used pure, despite its relative fertility, probably due to its low porosity, which causes compaction of the substrate.

Mexal and Lands describe the trait plant height (PHEI) as providing an optimal estimate of the prediction of the initial development of seedlings in a field, being technically one of the main traits accepted as performance potential of plants. Gomes et al. (2002) cite this trait, when particularly evaluated, may be used to express seedling quality.

The seedlings presented a higher height in treatment T3, with 50\% of sewage sludge combined with the substrate, thus differing from the other treatments. Treatments that used $0 \%$ (T2) and 75\% (T5) of sewage sludge obtained the lowest values of the growth traits under evaluation. These results differ from the ones found by Nóbrega et al. (2007), who verified an increasing trend in the values of this parameter for the species Schinus terebynthifolius from the first dose of sewage sludge $(20 \%)$ added to the subsoil substrate.

The positive effect of the substrate enriched with sewage sludge at the seedling height may also be linked to the greater availability of $\mathrm{P}, \mathrm{Ca}, \mathrm{Mg}$, and $\mathrm{K}$ and to the $\mathrm{pH}$, at levels appropriate for plant growth (Table 2). In their 
researches, Dias et al. (2009) have proven that the addition of organic compound to the substrates used for seedling production, results in benefits like the supply of macro- and micro-nutrients.

In the view of a number of researchers, root collar diameter and root length are key traits to estimate field graft rates for different crops (Carneiro, 1995; Daniel et al., 1997; Gomes et al., 2002; Souza et al., 2006; Dardengo et al., 2013). These variables are also used in determining fertilizer doses and the ability to survive in the field (Souza et al., 2006; Dardengo et al., 2013).

The substrates of the treatments $50 \% \mathrm{~T} 3$ of sewage sludge, in which the optimal dosages were close to $50 \% \mathrm{~T} 3$ ranging from $42 \%$ to $46.87 \%$, were the most appropriate (Table 3), suggesting that sewage sludge can be an alternative for composing the substrate to a volume of $50 \%$ associated to $50 \%$ of soil, without losses in diameter growth, in the conditions under which the experiment was conducted.

The K supply (Table 2), in treatments with the best mean diameter (T2, T3, and T4), together with physical properties of the soil, may have played a role in the root system development due to the important function of potassium in the stomatal aperture (Valeri \& Corradini, 2005).

The number of leaves (NL), total fresh matter (TFM), and fresh matter of aerial part (FMAP) had the ideal dosages with percentages of $42.21 ; 41.95$; and $39.91 \%$, respectively. Thus, for root fresh matter (RFM), its percentage was of only $22.50 \%$ (Table 3 ).

Results obtained in T3 confirm the dosages found in the other variables investigated, pointing to the relationship between plant height and fresh matter yield. While similar dosages have been found for plant height and root fresh matter, a number of researchers have not indicated substrates which contain mineral soil, because it can reduce porosity and increase substrate density, inhibiting root system development and, consequently, the aerial part due to the increase in salinity caused by the high potassium content (Kämpf, 2002).

Gomes and Paiva (2006) pointed out that there is a relationship between the factors that affect plant height and gain of fresh matter and dry matter, which may be related to the nutritional factors of sewage sludge with the greater availability of $\mathrm{N}, \mathrm{P}, \mathrm{Ca}, \mathrm{Mg}$, and $\mathrm{K}$ and with the $\mathrm{pH}$ in substrates that led to better growth of the evaluated traits (Table 3).

The dry matter of aerial part and root dry matter have been considered by several authors as two of the best traits to estimate the seedling survival and its initial growth in the field (Caldeira et al., 2008a, 2000b; Gomes et al., 2002). As a whole, sewage sludge applied to the subsoil had positive effects as it increased the dry matter yield, as can be seen in Table 3. The treatment $\mathrm{T} 3$ with $50 \%$ sewage sludge provided the best performance of the plants.

Also, as the dose of sewage sludge in the substrate increased, a positive effect was produced on the accumulation of total dry matter up to a ratio of 57\%:43\% (sewage sludge: subsoil), by which a greater increase for the analyzed trait was achieved, which can lead to the acquisition of seedlings with greater survival in the field.

No significant increase was obtained in the root dry matter in ratios above $60 \%$ of sewage sludge (T4), most likely because of the undesirable changes in physical characteristics (macro and microporosity) the use of high concentrations of sewage sludge can cause to the substrate (Trazzi, 2011; Trazzi et al., 2010).

For the traits plant height and root collar diameter ratio (HEI/RCD), dry matter of aerial part and root dry matter ratio (DMAP/RDM), and Dickson quality index (DQI), there was an effect by regression coefficients with $97 \%$ and $81 \%$ and $90 \%$, in which the optimal doses of sewage sludge were $0 \%$ and $75 \%$ and $50 \%$, respectively (Figures 1, 2, and 3). The increase in sewage sludge doses led to an increment in the DMAP/RDM ratio, while the same did not occur in the PHEI/RCD ratio and the Dickson quality index DQI. 


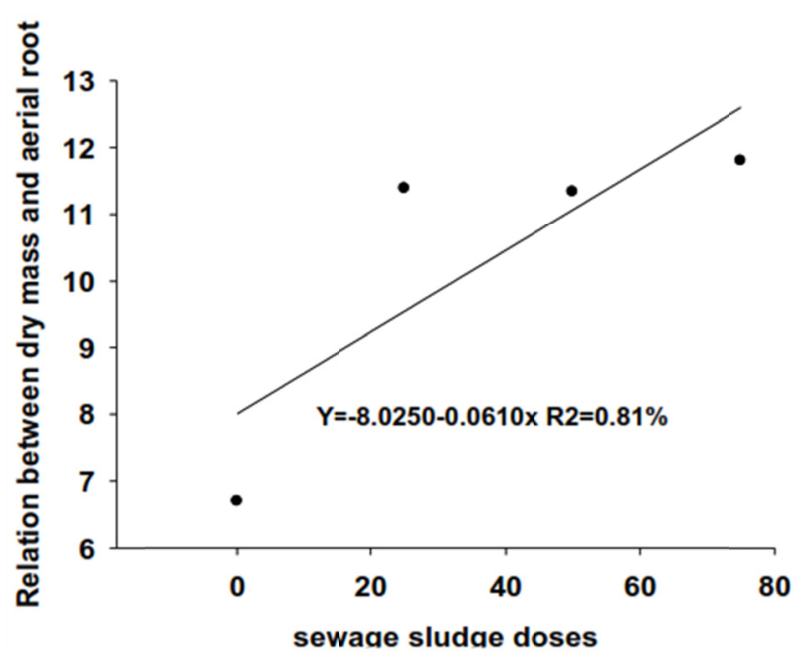

Figure 1. Ratio between plant height and root collar diameter (HEI/RCD) for yellow passion fruit plants exposed to different concentrations of sewage sludge in substrates

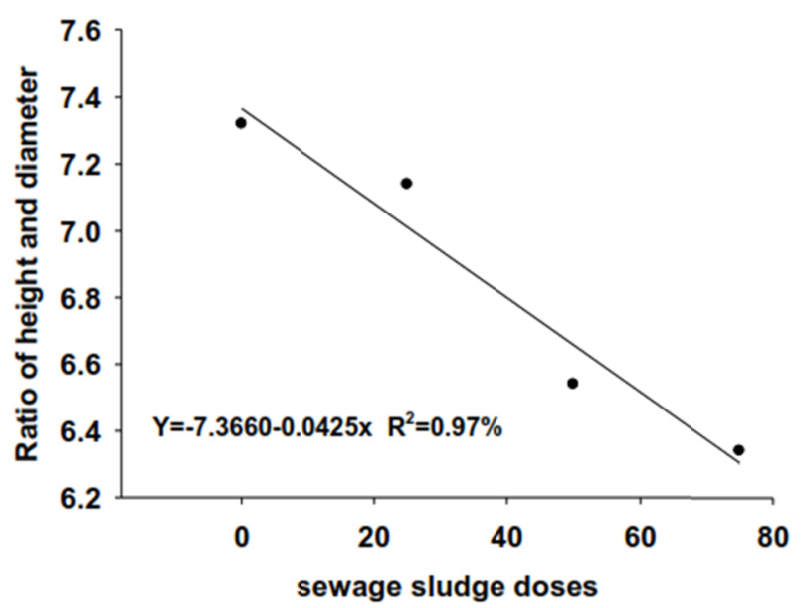

Figure 2. Ratio between dry matter of aerial part and root dry matter (DMAP/RDM) for yellow passion fruit plants exposed to different concentrations of sewage sludge in substrates

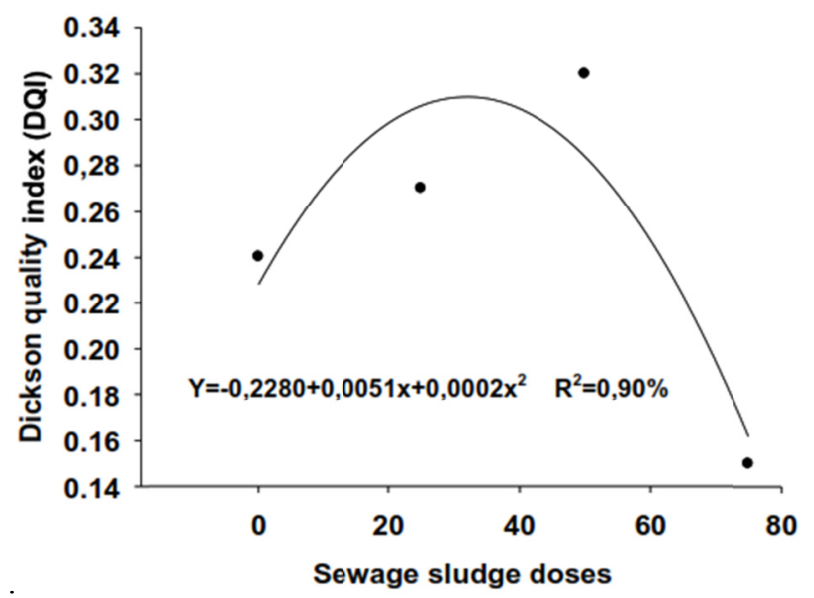

Figure 3. Dickson quality index (DQI) for yellow passion fruit plants exposed to different concentrations of sewage sludge in substrates 
Dickson quality index (DQI) is pointed out as an excellent seedling quality indicator, as, for its calculation, it is considered robustness, ratio (HEI/RCD), and biomass distribution balance, ratio (DMAP/RDM) (Caldeira et al., 2005, 2007; Fonseca et al., 2002; Trazzi, 2011), weighing the results of significant morphological traits employed in the quality evaluation. The higher the DQI, the better the seedling quality produced (Gomes et al., 2002).

Testing diverse substrate formulations with sewage sludge, carbonized rice husk and coconut fiber, Trazzi (2011) confirmed that the DQI values ranged from 0.4 to 2.32 for Tectona grandis seedlings. The highest mean was for treatments $\mathrm{T} 7(60 \% \mathrm{SS}+40 \% \mathrm{CF})$ and $\mathrm{T} 8(40 \% \mathrm{SS}+60 \% \mathrm{CF})$, statistically differing from the other treatments. The results of the current study were conflicting, with values between 0.15 and 0.32 (Figure 9), while the best means were achieved in high concentrations of sewage sludge in the concentration $50 \%$.

Results from this study were lower than the ones in Tabebuia impetiginosa, in which mean values ranged from 6.21 to 7.25 (Cunha et al., 2005); nevertheless, higher values were achieved by Gomes and Paiva (2006), who recommended DQI higher than 0.2 for Pseudotsuga menziesii and Picea abies seedlings. Different results were achieved in treatment T4, which presented a lower index, but not lower enough to classify it as low-quality seedlings, once they result from different species to the index recommended by Gomes and Paiva (2006).

As stated by (Caldeira et al., 2000a, 2000b, 2005, 2007, 2008a, 2008b; Kratz, 2011; Saidelles et al., 2009; Trazzi, 2011; Trazzi et al., 2010), DQI is a variable characteristic which depends on the species, seedling management in the nursery, type and proportion of substrate, container volume and, mainly, the age at which the seedlings were evaluated.

\section{Conclusions}

The regression coefficients were above $80 \%$, and the morpho-agronomic traits obtained different optimal doses of sewage sludge for substrate preparation.

The use of sewage sludge as a component of substrates is a feasible option for the final disposal of this residue.

On the basis of the Dickson quality index evaluated, the use of $50 \%$ of sewage sludge may be recommended for the formulation of substrates for the yellow passion fruit seedling production.

\section{References}

Baliza, D. P., Oliveira, A. L. D., Dias, R. A. A., Guimarães, R. J., \& Barbosa, C. R. (2013). Antecipação da produção e desenvolvimento da lavoura cafeeira implantada com diferentes tipos de mudas. Coffee Science, $8(1), 61-68$.

Cavalcante, Í. H. L., Cavalcante, L. F., dos Santos, G. D., Beckmann-Cavalcante, M. Z., \& de Melo Silva, S. (2012). Impact of biofertilizers on mineral status and fruit quality of yellow passion fruit in Brazil. Communications in Soil Science and Plant Analysis, 43(15), 2027-2042. https://oi.org/10.1080/00103624. 2012.693234

Cruz, C. D., Regazzi, A. J., \& Carneiro, P. C. S. (2004). Modelos biométricos aplicados ao melhoramento genético (Vol. 1). Viçosa, Editora UFV.

Dardengo, M. C. J., Sousa, E. F. D., Reis, E. F. D., \& Gravina, G. D. A. (2013). Crescimento e qualidade de mudas de café conilon produzidas em diferentes recipientes e níveis de sombreamento. Coffee Science, 8(4), 500-509.

Dias, R., \& Melo, B. D. (2009). Proporção de material orgânico no substrato artificial para a produção de mudas de cafeeiro em tubetes. Ciência e Agrotecnologia, 33(1), 144-152. https://doi.org/10.1590/S1413-70542 009000100021

Dias, R., Melo, B. D., Rufino, M. D. A., Silveira, D. L., Morais, T. P. D., \& Santana, D. G. D. (2009). Fontes e proporção de material orgânico para a produção de mudas de cafeeiro em tubetes. Ciência e Agrotecnologia, 33(3), 758-764. https://doi.org/10.1590/S1413-70542009000300014

Faleiro, F. G., Junqueira, N. T. V., Braga, M. F., Bellon, G., \& Peixoto, J. R. (2006). Diversidade genética de variedades comerciais de maracujazeiro-azedo com base em marcadores moleculares (pp. 105-109). Embrapa Cerrados.

Freitas, J. P. X., de Oliveira, E. J., da Cruz Neto, A. J., \& dos Santos, L. R. (2011). Avaliação de recursos genéticos de maracujazeiro-amarelo. Pesquisa Agropecuária Brasileira, 46(9), 1013-1020.

Hair, J. F., Black, W. C., Babin, B. J., Anderson, R. E., \& Tatham, R. L. (2009). Análise multivariada de dados (5th ed., p. 592). Bookman Editora. 
Heras, J. D. L., Mañas, P., \& Labrador, J. (2005). Effects of several applications of digested sewage sludge on soil and plants. Journal of Environmental Science and Health, 40(2), 437-451. https://oi.org/10.1081/ ESE-200045646

Konzen, E. A., \& Alvarenga, R. C. (2005). Manejo e utilização de dejetos de suinos: Aspectos agronômicos e ambientais (Vol. 63, p. 16). Embrapa Milho e Sorgo-Circular Técnica (INFOTECA-E).

Leite, R. L. B. D. L., \& Sinigaglia, E. C. C. (2005). Divergência genética entre populações de cebola com base em marcadores morfológicos. Ciência Rural, 35(2). https://doi.org/10.1590/S0103-84782005000200009

Magalhães Bertini, C. H. C., Pinheiro, E. A. R., Nóbrega, G. N., \& de Lima Duarte, J. M. (2010). Desempenho agronômico e divergência genética de genótipos de coentro. Revista Ciência Agronômica, 41(3), 409-416. https://doi.org/10.1590/S1806-66902010000300013

Maggio, A., De Pascale, S., Paradiso, R., \& Barbieri, G. (2013). Quality and nutritional value of vegetables from organic and conventional farming. Scientia Horticulturae, 164, 532-539. https://doi.org/10.1016/ j.scienta.2013.10.005

Marana, J. P., Miglioranza, É., Fonseca, É. D. P., \& Kainuma, R. H. (2008). Índices de qualidade e crescimento de mudas de café produzidas em tubetes. Ciência Rural, 38(1), 39-45. https://doi.org/10.1590/ S0103-84782008000100007

McBride, M. B. (2003). Toxic metals in sewage sludge-amended soils: has promotion of beneficial use discounted the risks? Advances in Environmental Research, 8(1), 5-19. doi: https://oi.org/10.1016/ S1093-0191(02)00141-7

McLaren, R. G., Clucas, L. M., Taylor, M. D., \& Hendry, T. (2004). Leaching of macronutrients and metals from undisturbed soils treated with metal-spiked sewage sludge. 2. Leaching of metals. Soil Research, 42(4), 459-471. https://doi.org/10.1071/SR04109

Oliveira, A. B., de Almeida Lopes, M. M., Moura, C. F. H., de Siqueira Oliveira, L., de Souza, K. O., Gomes Filho, E., \& de Miranda, M. R. A. (2017). Effects of organic vs. conventional farming systems on quality and antioxidant metabolism of passion fruit during maturation. Scientia Horticulturae, 222, 84-89. https://doi.org/10.1016/j.scienta.2017.05.021

Pacheco, A. L. V., Pagliarini, M. F., Vieira, G., \& de Freitas, G. B. (2016). Influência da adubação orgânica sobre a classificação e aparência dos frutos de maracujazeiro-amarelo. Revista Brasileira de Agropecuária Sustentável, 6(2), 43-50. https://doi.org/10.21206/rbas.v6i2.322

Pereira, A. V. (1989). Utilização de análise multivariada na caracterização de germoplasma de mandioca (Manihot esculenta Crantz) (p. 180, Tese, Doutorado em Genética e Melhoramento de plantas, Escola Superior de Agricultura "Luiz de Queiroz", Universidade de São Paulo, Piracicaba, SP).

Pereira, I. S., de Lima, K. C. C., \& de Melo Junior, H. B. (2017). Substratos orgânicos na produção de mudas de cafeeiro em tubetes. Journal of Neotropical Agriculture, 4(2), 17-26.

Prado, R. D. M., Corrêa, M. C. D. M., Cintra, A. C. O., \& Natale, W. (2003). Resposta de mudas de goiabeira à aplicação de escória de siderurgia como corretivo de acidez do solo. Revista Brasileira de Fruticultura, 25(1), 160-163.

Rodrigues, L. S., Teixeira, M. G., \& da Silva, J. B. (2002). Divergência genética entre cultivares locais e cultivares melhoradas de feijão. Pesquisa Agropecuária Brasileira, 37(9), 1275-1284.

Sabião, R. R., Silva, A. D. C. C. D., Martins, A. B. G., \& Cardoso, E. R. (2011). Cutting rooting of Passiflora nitida submitted to different concentrations of indol butyric acid (IBA). Revista Brasileira de Fruticultura, 33(SP1), 654-657.

San-tana de Almeida, S. L., Cogo, F. D., Gonçalves, B. O., Ribeiro, B. T., Campos, K. A., \& de Morais, A. R. (2011). Adição de resíduos orgânicos ao substrato para produção de mudas de café em tubete. Revista Agrogeoambiental, 3(2), 9-13. https://doi.org/10.18406/2316-1817v3n22011326

Santos, C. D., Kist, B. B., Carvalho, C. D., Reetz, E. R., \& Drum, M. (2014). Anuário brasileiro da fruticultura. Santa Cruz do Sul: Gazeta Santa Cruz do Sul-RS.

Sousa, J. I. (2005). Poda das plantas frutíferas (p. 191). NBL Editora. São Paulo: Nobel.

Taiz, L., Zeiger, E., Møller, I. M., \& Murphy, A. (2017). Fisiologia e desenvolvimento vegetal. Artmed Editora. 


\section{Copyrights}

Copyright for this article is retained by the author(s), with first publication rights granted to the journal.

This is an open-access article distributed under the terms and conditions of the Creative Commons Attribution license (http://creativecommons.org/licenses/by/4.0/). 